\title{
The Effectiveness of Rotational Blended Learning Strategy on the Mathematical Word Problem Solving Skills of Grade IV Pupils
}

\author{
Junil A. Constantino, Ruby A. Constantino
}

Nueva Ecija University of Science and Technology, Gapan North Central School, Philippines

Received: 28 Sept 2020; Received in revised form: 10 Nov 2020; Accepted: 15 Nov 2020; Available online: 19 Nov 2020 (C)2020 The Author(s). Published by Infogain Publication. This is an open access article under the CC BY license (https://creativecommons.org/licenses/by/4.0/).

\begin{abstract}
This study focused on the performance of the at-risk pupils in solving mathematical word problems before and after the use of the rotational blended learning strategy. The research adopted the Pretest - Posttest design which dealt with two groups. Data obtained were processed through the Statistical Package for Social Sciences (SPSS) using mean and t-test. Findings revealed that before the use of given mathematical learning competencies, both the controlled group and experimental group have average performance levels. But after the use of given mathematical learning competencies, both groups have an improved average performance level. It is recommended that the school leaders and local educational policy makers planned the development of rotational blended learning strategy for classroom use.
\end{abstract}

Keywords-Rotational Blended Learning Strategy, Mathematical Word Problem, Solving Skills, AtRisk Pupils, Grade IV.

\section{INTRODUCTION}

Word problems in Mathematics is an innovative way of presenting activities in textual form that can be read and understand rather than in abstract form (symbols and notations). In dealing with mathematical word problems, one must have a mental representation and understanding skills to comprehend the written text in a problem. It is in the task of the teacher to make sure that students get both skills (Boonen et al., 2016). Teachers need to be innovative and creative in using technology to guide their students. It comes as a challenge most importantly to the elementary teachers because getting the attention of students at an early age poses a big threat for learning to take place. Blended learning model is an excellent way to address the short attention span of students on learning. In a study of student attention, trained observers watched students during a lecture and recorded perceived breaks in attention. They noted attention lapses during the initial minutes of "settling-in," again at 10-18 minutes into the lecture, and then as often as every 3-4 minutes toward the end of class. (Wilson, et.al, 2007). In a study, students who are taught with blended learning feel happier and attractive not easily bored during the lesson. Blended Learning can improve student activity, understanding concepts and student learning outcomes. (Fitri, S., \& Zahari, C. L., 2019).

In a research conducted in one of the schools in the Philippines, students showed positive perceptions about the blended courses in terms of their relevance to learning and in capturing students' interest. Also, students indicated that compared to their non-blended courses there is an increase in the amount and quality of interaction between teachers and other students. (Alontaga, et.al. 2013)

It has been shown in studies that there was a change in behavior of students that uses media supported by Blended Learning Strategy. Being inquisitive, critical thinker, open-mindedness, cooperative, persevere, and with respect to the data and fact are the effects on scientific attitudes of students. Further, it makes the students enthusiastically eager to begin early and make it until the 
end of learning with the use of e-learning media supported student worksheet. (Budiharti \& Waras, 2018)

Further researches shows that students in the blended course were more satisfied with using technology to facilitate and help them improve their learning than students in the traditional course. Students in the blended course had more positives perceptions of their learning experiences than students in the traditional course The perception of the majority of the students in both courses

indicated a positive view of technology use in the classroom. The findings further suggest that student participants would choose blended course delivery as an alternative to face-to-face instruction. (Arano-Ocuaman, J.,2010)

In terms of test scores, one research revealed that an instruction using technology in the mathematics posttest results of the students is significantly higher than the posttest results of the groups who were instructed without technology. (E. Ramadan \& Yaratan, Hüseyin, 2014) Therefore, the infusion of technology as part of learning is essential for academic achievement of students.

On the other hand, the use of technological tools holds a promising aid for the teachers to plan their work with ease and therefore creating a conducive atmosphere for learning. It is evident in many researches that technology intervention had a positive effect on students' attitudes toward and use of computers for educational purposes. (Gibson, et.al, 2014)

The importance of blended learning strategy comes from the student feeling towards this method, they feel that they play a major role during learning and because they have the option to choose which method of learning suitable to them. Finally, using blended learning strategy as a teaching method, reflect on raising student achievement and improving their attitudes towards learning. Moreover, it develops student's skills, including: communication skills, receiving information, and the interaction between the student and the teacher. Blended learning strategy saves the time for both the teacher and the student.

This action research was designed primarily to determine the effectiveness of the rotational blended learning strategy to the mathematical problem solving ability of Grade IV at-risk pupils of Gapan North Central School during the School Year 2019-2020.

Specifically, this research study attempted to answer the following questions:
1. How may the performance of the at-risk pupils in solving mathematical word problems be described before the use of the rotational blended learning strategy?

2. How may the performance of the at-risk pupils in solving mathematical word problems be described after the use of the rotational blended learning strategy?

3. Is there a significant difference between the performance of the at-risk pupils in solving mathematical word problems before and after the use of the rotational blended learning strategy?

\section{METHODOLOGY}

\section{A. Type of Research}

Mainly, the study was an experimental research because it attempted to examine the ability of the at-risk pupils in solving mathematical word problems before and after the use of rotational blended learning strategy.

The research also adopted the Pretest-Posttest Design which dealt with a two groups of pupils and the results compared to determine the effectiveness of the rotational blended learning strategy in the mathematical problemsolving ability of the Grade IV pupils.

On the other hand, T-test was employed on the attempt to determine the significant difference between the performance of the at-risk pupils in solving mathematical word problems before and after the use of the rotational blended learning strategy.

\section{B. Respondents and Sampling Method}

The purposive sampling technique was used in determining the respondents of this study, as to who will be included in the controlled group and the experimental group.

The table below shows the distribution of the studentrespondents.

\begin{tabular}{|l|l|l|}
\hline \multicolumn{1}{|c|}{$\begin{array}{c}\text { Controlled } \\
\text { Group }\end{array}$} & $\begin{array}{c}\text { Experimental } \\
\text { Group }\end{array}$ & Total \\
\hline 20 & 20 & 40 \\
\hline
\end{tabular}

Forty (40) grade 4 at risk pupils under the mathematics class of the proponent during the School Year 2019-2020 were the main participants of this study. The proponent's research locale was Gapan North Central School.

The controlled group was not given any learning intervention. They were subjected to the traditional teaching-learning process. 
On the other hand, pupils under the experimental group were subjected to the intervention which was the rotational blended learning strategy.

\section{Instrument}

The diagnostic tests (Pre-test and Post-test) was used to determine the competency of the at-risk pupils in solving mathematical word problems. Constructed by the proponent, it is composed of 15 items for each 8 learning competencies: Envision numbers up to 100000 with focused on numbers 10 from 1 to 100000 , Gives the place value and value of a digit in numbers up to 100000 , Compare numbers up to 100000 using relation symbols, Orders numbers up to 100000 in increasing or decreasing order, Multiplies numbers up to 3- digit numbers by up to 2-digit numbers without or with regrouping, Solves routine and non-routine problems involving multiplication of whole numbers including money using appropriate problem solving strategies and tools, Divides 3- to 4-digit numbers by 1-to 2-digit numbers without and with remainder, and Divides 3- to 4-digit numbers by tens or hundreds or by 1000 without and with remainder. The use of the average weighted mean using a 3-point scale was also employed.

$\begin{array}{lll}\text { Scale } & \text { Weighted Mean } & \text { Verbal Interpretation } \\ 12.50 & 10.00-15.00 & \text { Outstanding } \\ 7.50 & 5.00-9.99 & \text { Average } \\ 2.50 & 0-4.99 & \text { Poor }\end{array}$

\section{$\underline{\underline{D}}$. Data Collection and Ethical Considerations}

The official approval of this research was obtained by submitting it to the Division Research Evaluation Committee for evaluation and eventual acceptance for implementation.

Specifically, 40at-risks pupils were the participants of the study. The pupils were administered a diagnostic test prior to the implementation of the rotational blended learning strategy. The scores they obtained were recorded.

The implementation phase immediately followed. At the end of the implementation of the rotational blended learning strategy, the proponent once again gave a diagnostic test to the participants. Their scores were tabulated.

The data gathered were processed by the researcher to statistical analysis to facilitate the data interpretations.

\section{E. Data Analysis}

The data that were obtained were processed through the Statistical Package for Social Sciences (SPSS) using the following statistical methods:

1. Mean to determine the performance of the at-risk pupils in solving mathematical word problems.

2. T-test to determine the significant difference between the performance of the at-risk pupils in solving mathematical word problems before and after the use of the rotational blended learning strategy.

\section{RESULTS AND DISCUSSIONS}

\section{Level of Performance of the Pupils Before the Use of Rotational Blended Learning Strategy}

\begin{tabular}{|l|l|l|l|l|}
\hline $\begin{array}{l}\text { Learning } \\
\text { Competencies }\end{array}$ & \multicolumn{2}{|l|}{$\begin{array}{l}\text { Experimental } \\
\text { Group }\end{array}$} & \multicolumn{2}{l|}{ Controlled Group } \\
\cline { 2 - 5 } & $\begin{array}{l}\text { Avera } \\
\text { ge } \\
\text { Score } \\
\text { s }\end{array}$ & $\begin{array}{l}\text { Verbal } \\
\text { Interpr } \\
\text { etation }\end{array}$ & $\begin{array}{l}\text { Avera } \\
\text { ge } \\
\text { Score } \\
\text { s }\end{array}$ & $\begin{array}{l}\text { Verbal } \\
\text { Interpret } \\
\text { ation }\end{array}$ \\
\hline $\begin{array}{l}\text { Visualizes numbers } \\
\text { up to 100 000 with } \\
\text { emphasis on } \\
\text { numbers 10 001 - } \\
\text { 100 000. }\end{array}$ & 6.10 & $\begin{array}{l}\text { Averag } \\
\text { e }\end{array}$ & 7.10 & Average \\
\hline $\begin{array}{l}\text { Gives the place } \\
\text { value and value of a } \\
\text { digit in numbers up } \\
\text { to 100 000. }\end{array}$ & 8.20 & $\begin{array}{l}\text { Averag } \\
\text { e }\end{array}$ & 7.50 & Average \\
\hline $\begin{array}{l}\text { Compares numbers } \\
\text { up to 100 000 using } \\
\text { relation symbols. }\end{array}$ & 5.50 & $\begin{array}{l}\text { Averag } \\
\text { e }\end{array}$ & 6.50 & Average \\
\hline $\begin{array}{l}\text { Orders numbers up } \\
\text { to 100 000 in } \\
\text { increasing or } \\
\text { decreasing order. }\end{array}$ & 9.10 & $\begin{array}{l}\text { Averag } \\
\text { e }\end{array}$ & 6.35 & Average \\
\hline $\begin{array}{l}\text { Multiplies numbers } \\
\text { up to 3- digit } \\
\text { numbers by up to 2- } \\
\text { digit numbers } \\
\text { whithout or with } \\
\text { regrouping. } \\
\text { non-routine }\end{array}$ & 7.10 & $\begin{array}{l}\text { Averag } \\
\text { e }\end{array}$ & 8.50 & Average \\
\hline $\begin{array}{l}\text { Solves routine and } \\
\text { Average }\end{array}$ & & & \\
\hline
\end{tabular}




\begin{tabular}{|c|c|c|c|c|}
\hline $\begin{array}{l}\text { including money } \\
\text { using appropriate } \\
\text { problem solving } \\
\text { strategies and tools. }\end{array}$ & & & & \\
\hline $\begin{array}{l}\text { Divides } 3 \text { - to 4-digit } \\
\text { numbers by -to 2- } \\
\text { digit numbers } \\
\text { without and with } \\
\text { remainder. }\end{array}$ & 9.05 & $\begin{array}{l}\text { Averag } \\
\mathrm{e}\end{array}$ & 8.33 & Average \\
\hline $\begin{array}{l}\text { Divides } 3 \text { - to } 4 \text {-digit } \\
\text { numbers by tens or } \\
\text { hundreds or by } 1 \\
000 \text { without and } \\
\text { with remainder. }\end{array}$ & 4.35 & Poor & 4.85 & Poor \\
\hline Average & 7.18 & $\begin{array}{l}\text { Averag } \\
\mathrm{e}\end{array}$ & 7.24 & Average \\
\hline
\end{tabular}

Legend: $10.50-15.00=$ Outstanding; $5.60-10.40=$ Average; $1.00-5.40=$ Poor

Before the use of the intervention, both the controlled and experimental groups had difficulty when it comes to their performance in mathematics lessons particularly in multiplying numbers up to 3 - digit numbers by up to 2-digit numbers without or with regrouping.

Both groups had an average performance in the following competencies: visualizes numbers up to 100000 with focused on numbers $10001-100000$ (experimental group: 6.10; controlled group: 7.10); gives the place value and value of a digit in numbers up to $100 \quad 000$ (experimental group: 8.20; controlled group: 7.50); compares numbers up to 100000 using relation symbols (experimental group: 5.50; controlled group: 6.50); orders numbers up to 100000 in increasing or decreasing order (experimental group: 9.10; controlled group: 8.80); multiplies numbers up to 3 - digit numbers by up to 2-digit numbers without or with regrouping (experimental group: 7.10; controlled group: 8.50); solves routine and nonroutine problems involving multiplication of whole numbers including money using appropriate problem solving strategies and tools (experimental group: 8.05; controlled group: 6.35); and divides 3- to 4-digit numbers by 1-to 2-digit numbers without and with remainder (experimental group: 9.05; controlled group: 8.33).

On the other hand, both groups had poor performance in dividing 3- to 4-digit numbers by tens or hundreds or by 1000 without and with remainder (experimental group: 4.35; controlled group: 4.85).

The findings imply that that majority of the pupilrespondents have difficulty in terms of performance when it comes to learning the given competencies.

\section{Level of Performance of the Pupils After the Use of Use of Rotational Blended Learning Strategy}

\begin{tabular}{|c|c|c|c|c|}
\hline \multirow[t]{2}{*}{$\begin{array}{l}\text { Learning } \\
\text { Competencies }\end{array}$} & \multicolumn{2}{|c|}{$\begin{array}{l}\text { Experimental } \\
\text { Group }\end{array}$} & \multicolumn{2}{|c|}{$\begin{array}{l}\text { Controlled } \\
\text { Group }\end{array}$} \\
\hline & $\begin{array}{l}\text { Average } \\
\text { Scores }\end{array}$ & $\begin{array}{l}\text { Verba } \\
1 \\
\text { Interp } \\
\text { retati } \\
\text { on }\end{array}$ & $\begin{array}{l}\text { Averag } \\
\text { e } \\
\text { Scores }\end{array}$ & $\begin{array}{l}\text { Verbal } \\
\text { Interpr } \\
\text { etation }\end{array}$ \\
\hline $\begin{array}{l}\text { Visualizes numbers } \\
\text { up to } 100000 \text { with } \\
\text { emphasis on } \\
\text { numbers } 10001- \\
100000 .\end{array}$ & 9.10 & $\begin{array}{l}\text { Avera } \\
\text { ge }\end{array}$ & 8.25 & $\begin{array}{l}\text { Averag } \\
\text { e }\end{array}$ \\
\hline $\begin{array}{l}\text { Gives the place } \\
\text { value and value of } \\
\text { a digit in numbers } \\
\text { up to } 100000 .\end{array}$ & 10.20 & $\begin{array}{l}\text { Outst } \\
\text { andin } \\
\mathrm{g}\end{array}$ & 8.30 & $\begin{array}{l}\text { Averag } \\
\mathrm{e}\end{array}$ \\
\hline $\begin{array}{l}\text { Compares numbers } \\
\text { up to } 100000 \\
\text { using relation } \\
\text { symbols. }\end{array}$ & 9.50 & $\begin{array}{l}\text { Avera } \\
\text { ge }\end{array}$ & 7.50 & $\begin{array}{l}\text { Averag } \\
\text { e }\end{array}$ \\
\hline $\begin{array}{l}\text { Orders numbers up } \\
\text { to } 100000 \text { in } \\
\text { increasing or } \\
\text { decreasing order. }\end{array}$ & 9.80 & $\begin{array}{l}\text { Avera } \\
\text { ge }\end{array}$ & 8.80 & $\begin{array}{l}\text { Averag } \\
\text { e }\end{array}$ \\
\hline $\begin{array}{l}\text { Multiplies numbers } \\
\text { up to } 3 \text { - digit } \\
\text { numbers by up to } \\
\text { 2-digit numbers } \\
\text { without or with } \\
\text { regrouping. }\end{array}$ & 10.10 & $\begin{array}{l}\text { Outst } \\
\text { andin } \\
\mathrm{g}\end{array}$ & 8.80 & $\begin{array}{l}\text { Averag } \\
\text { e }\end{array}$ \\
\hline $\begin{array}{l}\text { Solves routine and } \\
\text { non-routine } \\
\text { problems involving } \\
\text { multiplication of } \\
\text { whole numbers } \\
\text { including money } \\
\text { using appropriate } \\
\text { problem solving } \\
\text { strategies and tools. }\end{array}$ & 9.05 & $\begin{array}{l}\text { Avera } \\
\text { ge }\end{array}$ & 7.85 & $\begin{array}{l}\text { Averag } \\
\text { e }\end{array}$ \\
\hline $\begin{array}{l}\text { Divides 3- to } 4 \text { - } \\
\text { digit numbers by } 1 \text { - } \\
\text { to } 2 \text {-digit numbers } \\
\text { without and with } \\
\text { remainder. }\end{array}$ & 12.10 & $\begin{array}{l}\text { Outst } \\
\text { andin } \\
\mathrm{g}\end{array}$ & 9.33 & $\begin{array}{l}\text { Averag } \\
\mathrm{e}\end{array}$ \\
\hline
\end{tabular}




\begin{tabular}{|l|l|l|l|l|}
\hline $\begin{array}{l}\text { Divides 3- to 4- } \\
\text { digit numbers by } \\
\text { tens or hundreds or } \\
\text { by 1 000 without } \\
\text { and with } \\
\text { remainder. }\end{array}$ & 9.30 & $\begin{array}{l}\text { Avera } \\
\text { ge }\end{array}$ & 7.45 & $\begin{array}{l}\text { Averag } \\
\text { e }\end{array}$ \\
\hline Average & 9.89 & $\begin{array}{l}\text { Avera } \\
\text { ge }\end{array}$ & 8.29 & $\begin{array}{l}\text { Averag } \\
\text { e }\end{array}$ \\
\hline
\end{tabular}

Legend: $10.00-15.00=$ Outstanding; $5.00-9.99=$ Average;

$0.00-4.99=$ Poor

After the use of the intervention, both the controlled and experimental groups had improved when it comes to their performance in the given mathematical competencies.

Both groups had an average performance in the following competencies: visualizes numbers up to 100000 with emphasis on numbers $10001-100 \quad 000$ (experimental group: 9.10; controlled group: 8.25); compares numbers up to 100000 using relation symbols (experimental group: 9.50; controlled group: 7.50); orders numbers up to 100000 in increasing or decreasing order (experimental group: 9.80; controlled group: 8.80); solves routine and non-routine problems involving multiplication of whole numbers including money using appropriate problem solving strategies and tools (experimental group: 9.05; controlled group: 7.85); and in dividing 3- to 4-digit numbers by tens or hundreds or by 1000 without and with remainder (experimental group: 9.30; controlled group: 7.45).

In terms of giving the place value and value of a digit in numbers up to 100000 , the experimental group had an average score of 10.20 while the controlled group obtained 8.30.

The experimental group got an average score of 10.10 in multiplying numbers up to 3 - digit numbers by up to 2-digit numbers without or with regrouping while the experimental group scored 8.80 .

Lastly, in dividing 3- to 4-digit numbers by 1-to 2-digit numbers without and with remainder, the experimental group got an average score of 12.10 while the controlled group obtained 9.33 .

The findings imply that that majority of the pupilrespondents have a relatively improved performance levels in terms of academic performance when it comes to the given mathematics learning competencies.
3. Significant Difference in the Level of Performance of Both Groups Before and After the Use of Rotational Blended Learning Strategy for Grade IV

\begin{tabular}{|l|l|l|l|l|l|}
\hline Groups & $\begin{array}{l}\text { t- } \\
\text { valu } \\
\text { e }\end{array}$ & $\begin{array}{l}\text { Critic } \\
\text { al } \\
\text { Value }\end{array}$ & $\begin{array}{l}\text { p- } \\
\text { valu } \\
\text { e }\end{array}$ & Result & $\begin{array}{l}\text { Decisio } \\
\text { n }\end{array}$ \\
\cline { 1 - 3 } Controlled & 3.69 & 1.987 & $\begin{array}{l}0.00 \\
036\end{array}$ & $\begin{array}{l}\text { Signifi } \\
\text { cant at } \\
\text { p } \\
0.05\end{array}$ & $\begin{array}{l}\text { Reject } \\
\text { the null } \\
\text { hypothe } \\
\text { sis }\end{array}$ \\
\hline
\end{tabular}

The results showed that the absolute value of the computed t-value 3.6961 was greater than the critical value 1.987. It showed that the level of performance of the pupilrespondents in terms of the given mathematical learning competencies is significantly different at $\mathrm{p}<0.05$.

This validated that after the use of rotational blended learning strategy, the pupil-respondents, specifically the experimental group improved their level of performance. Hence, this gave the researcher a

generalization that the rotational blended learning strategy greatly helped the pupil-respondents improved their performance in given mathematical learning competencies and found to be effective.

\section{CONCLUSIONS}

From the findings gathered by the researcher, the following conclusions are drawn:

1. Before the teacher's use of given mathematical learning competencies, both the controlled group and experimental group have average performance levels (7.18 and 7.28, respectively).

2. After the teacher's use of given mathematical learning competencies, both the controlled group and experimental group had an improved average performance level (9.89 and 8.29 respectively).

3. As to t-test, the results showed that the absolute value of the computed t-value 3.6961 was greater than the critical value 1.987 . It showed that the level of performance of the pupil-respondents in terms of the given mathematical learning competencies is significantly different at $\mathrm{p}<0$. This validated that after the use of rotational blended learning strategy, the pupil-respondents, specifically the experimental group improved their level of performance. 


\section{RECOMMENDATIONS}

From the conclusions drawn, the following recommendations are suggested by the researcher:

1. Lower grade pupils may be exposed in the use of rotational blended learning strategy to enhance their mathematical learning competencies and other subject areas.

2. Mathematics teachers must maintain a focus in teaching given mathematical learning competencies.

3. The government of the Philippines in close collaboration with the Department of Education and other stakeholders in education should try and include in the mathematics curriculum a play-based format to facilitate teaching-learning in schools.

4. Development of rotational blended learning strategy for classroom use may be planned by the school leaders and local policy makers.

5. Similar study may be conducted in other learning

\section{REFERENCES}

[1] Alontaga, J. Q., Valderama, A. C., Dijamco, T. D. \& Mones, W. P.. (2013). Examining Blended Learning Experiences of Higher Education Students. Journal of Business, Education and Law, 18(1). Retrieved from http://ejournals.ph/form/cite.php?id=10255

[2] Alontaga, J. Q., Austria, M. M. \& Taduyo, M. B.. (2013). Blended Learning in Philippine Higher Education Institutions: The Jose Rizal University Experience. Journal of Business, Education and Law, 18(1). Retrieved from http://ejournals.ph/form/cite.php?id=10256

[3] Arano-Ocuaman, J. (2010). Differences in student knowledge and perception of learning experiences among non-traditional students in blended and face-to-face classroom delivery. ProQuest Dissertations and Theses. University of Missouri - Saint Louis, United States -Missouri.

[4] Boonen AJH, de Koning BB, Jolles J and Van der Schoot M (2016) Word Problem Solving in Contemporary Math Education: A Plea for Reading Comprehension Skills Training. Front. Psychol. 7:191. doi: 10.3389/fpsyg.2016.00191

[5] Budiharti, R., \& Waras, N. S. (2018). Analysis of Student's Scientific Attitude Behaviour Change Effects Blended Learning Supported by I-Spring Suite 8 Application. In Journal of Physics: Conference Series (Vol. 1022). Institute of Physics Publishing. https://doi.org/10.1088/17426596/1022/1/01202

[6] Dennis, J.S. (2020). The Effects of Rotational Blended Learning on Course Grades in High School Credit Recovery Math and English Courses. Liberty University, Lynchburg, VA
[7] Fakhir, Z. (2015). The Impact of Blended Learning on the Achievement of the English Language Students and their Attitudes towards it. Retrieved from https://meu.edu.jo/libraryTheses/5874904ebbd3b_1.pdf.

[8] Eyyam, Ramadan \& Yaratan, Hüseyin. (2014). Impact of Use of Technology in Mathematics Lessons on Student Achievement and Attitudes. Journal of Social Behavior and Personality. 42. 31-42. 10.2224/sbp.2014.42. .S31.

[9] Fitri, S., \& Zahari, C. L. (2019). The Implementation of Blended Learning to Improve Understanding of Mathematics. In Journal of Physics: Conference Series (Vol. 1188). Institute of Physics Publishing. https://doi.org/10.1088/1742-6596/1188/1/012109

[10] Gibson, P. A., Stringer, K., Cotten, S. R., Simoni, Z., O'Neal, L. J., \& Howell-Moroney, M. (2014). Changing teachers, changing students? the impact of a teacherfocused intervention on students' computer usage, attitudes, and anxiety. Computers and Education, 71, 165-174. https://doi.org/10.1016/j.compedu.2013.10.002

[11] Kuehn, Paul Richard. (2019). Function and Importance of Pre and Post-Tests. Retrieved from https://owlcation.com/academia/PrePost-Test-ADiagnostic-Tool-For-More-Effective-Teaching-of-EFL$\underline{\text { Students }}$

[12] Miraflor, R. C. 2019. Learning Resource Portal. Retrtived from https://lrmds.deped.gov.ph/detail/16991

[13] Wilson, Karen; Korn, James H. (2007) Topical Articles: Attention during Lectures--Beyond Ten Minute, Teaching of Psychology, v34 n2 p85-89 2007 Retrieved from https://eric.ed.gov/?id=EJ772424 